\title{
PENGARUH KEMAMPUAN MEMBACA KITAB KUNING TERHADAP KETERAMPILAN BERBICARA BAHASA ARAB
}

\author{
Almannah Wassalwa, Anisatul Mardiyah \\ Universitas Ibrahimy Situbondo \\ salwaelmanna90@gmail.com
}

\begin{abstract}
:
This research is The Effect of Reading Ability (Mastery) Kitab Kuning on Arabic speaking skills in Ma'had Aly Marhalah Ula women's class. In this study, the researcher aims to determine whether or not there is an effect on reading ability in speaking Arabic. This research method uses quantitative research methods. From the results of calculations combined with the literature review, the ability to read the yellow book affects speaking skills in Arabic can be seen by it, both from a theoretical and empirical point of view. The results of the calculated data value were obtained by the number 0.416 after being consulted into the moving value coefficient between $0.400-0.599$, which showed that it has a moderate category.
\end{abstract}

Keyword: competence, reading, speaking.

\section{PENDAHULUAN}

Pada umumnya motivasi dan dorongan mempelajari bahasa Arab di Indonesia adalah untuk tujuan agama, yaitu untuk mengkaji dan memperdalam ajaran islam dari sumbersumber yang berbahasa Arab, seperti AlQuran, Al-Hadits, kitab-kitab turats dan lainlainnya. Di samping itu, pembelajaran bahasa Arab di pondok-pondok pesantren terutama di pondok-pondok salaf, bertujuan untuk memahami kitab-kitab kuning yang notabenenya memuat ajaran-ajaran Islam, sehingga dapat dikatakan bahwa tujuan pembelajaran bahasa Arabnya adalah untuk studi Islam. ${ }^{1}$

Memiliki kemampuan berbahasa Arab dapat dimumpuni oleh siapa saja yang memang ingin menguasainya, karena bahasa Arab bukanlah bahasa utama, melainkan bahasa kedua setelah bahasa ibu. Namun tidak semudah itu dalam memahami bahasa Arab, melainkan ada hal yang paling mempengaruhi kemampuan dan kemahiran terebut yaitu bi'ah (lingkungan). Mengapa dikatakan demikian, karena jika seseorang ingin

\footnotetext{
1 Mustofa, Bisri dan Hamid, Abdul. Metode dan Strategi Pembelajaran Bahasa Arab. Malang: UINMALIKI Press, 2012. Hlm 09
}

memiliki kemampuan berbahasa Arab, salah satunya kemampuan berbicara misalnya, tapi tidak didukung dengan lingkungan sekitarnya, maka ia tidak akan berhasil. Secara teoritis mungkin orang tersebut dapat menguasainya, akan tetapi secara praktis sulit untuk mempraktekannya.

Sebagian orang berasumsi bahwa berbicara dengan bahasa arab atau membaca teks arab itu lebih sulit karena masih harus memikirkan kaidah kebahasaan (Qaidah Nahwu) yang sesuai sebagaimana mestinya. Namun sebagian orang yang memang gemar dengan bahasa Arab bahkan berkomunikasi dengan bahasa Arab baik secara aktif atau pasif (hanya sebagai pendengar saja) menganggap hal itu mudah.

Seperti telah disinggung di atas, bahwa bahasa Arab merupakan media untuk mengkaji dan memperdalam ajaran Islam salah satunya kitab-kitab turast, maka bagi para pelajar terutama dipesantren salaf dituntut untuk bisa membaca teks arab yang tanpa tanda baca seperti syakl dan Syiddah atau lebih di kenal dengan istilah kitab gundul.

Para pakar lebih dahulu mengedepankan keterampilan berbicara, namun ternyata dengan menggunakan metode langsung 
(berkomunikasi dengan bahasa arab secara langsung) kurang memberikan perhatian kepada kemahiran membaca dan menulis, mendorong para guru dan para ahli bahasa untuk mencari metode baru. Oleh karena itu Profesor Coleman dan kawan-kawan dalam sebuah laporan yang ditulis pada tahun 1929 menyarankan penggunaan suatu metode dengan satu tujuan pengajaran yang lebih realistis, yang lebih di perlukan oleh pelajar, yakni keterampilan membaca. $^{2}$

Dalam keterampilan membaca ini, tidak berarti bahwa kegiatan belajar mengajar hanya terbatas pada latihan bacaan, latihan menulis dan berbicara juga di berikan akan tetapi dengan porsi terbatas. Dan tujuan utama dari keterampilan membaca ini adalah agar mampu memahami teks ilmiah untuk keperluan studi para pelajar.

Selain itu salah satu keterampilan bahasa Arab adalah keterampilan berbicara. Keterampilan berbicara adalah kemampuan mengungkapkan bunyi-bunyi artikulasi atau kata-kata untuk mengekspresikan pikiran berupa ide, pendapat, keinginan atau perasaan kepada mitra bicara. ${ }^{3}$ Banyak sekali manfaat dari keterampilan berbicara, salah satunya agar dapat berkomunikasi dengan bahasa asing serta dapat memahami dialog orang Arab yang begitu fasih.

Disamping hal itu keterampilan berbicara bahasa arab pun dikaitkan dengan kebutuhan nyata di masyarakat. Menjelang pertengahan abad-19, hubungan antar bangsa Eropa mulai terbuka sehingga menyebabkan adanya kebutuhan untuk bisa saling berkomunikasi aktif diantara mereka. ${ }^{4}$

Salah satu penopang utama agar dapat membaca teks Arab (kitab kuning) atau berbicara adalah nahwu dan shorf. Dengan menguasai kaidah kebahasaan maka akan dengan mudah memiliki keterampilan bahasa Arab. Karena ilmu Nahwu dan Shorf termasuk cabang-cabang ilmu bahasa Arab yang paling

\footnotetext{
${ }^{2}$ Ainin, Moh. 2007, metodologi penelitian Bahasa Arab, Malang: Hilal Pustaka, hlm 52

${ }^{3}$ Hermawan, Acep. Metodologi Pembelajaran Bahasa Arab, Bandung: Remaja Rosdakarya, 2011, hlm 135

${ }^{4}$ Ainin, Moh. 2007, metodologi penelitian Bahasa Arab, Malang: Hilal Pustaka, hlm 45
}

didahulukan. Maka tak salah jika ada perkataan $^{5}$ :

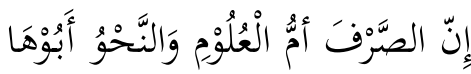

$$
\begin{aligned}
& \text { “ Sharf itu adalah ilmu dari } \\
& \text { berbagai ilmu sedangkan nahwu } \\
& \text { bapaknya" }
\end{aligned}
$$

Ma'had 'Aly merupakan salah satu lembaga pendidikan yang memfokuskan pada kajian kitab-kitab klasik (kitab kuning) khususnya dalam kajian kitab fiqh. Di lembaga tersebut lebih menekankan pada kemampuan membaca serta menelaah (memahami) kitab kuning. Kitab kuning adalah suatu istilah yang digunakan oleh sebagian kaum muslimin di Indonesia untuk menyebut kitab-kitab agama Islam yang berbahasa Arab, baik kitab tersebut membahas Aqidah, Hadits, Ilmu Mushtholah Hadits, Tafsir, Fiqih, Ushul Fiqih, Nahwu dan Shorof (sastra Arab), Sejarah Nabi.

Tak jarang diantara para siswa mahir dalam membaca kitab gundul (tanpa harakat dan makna), namun disamping pembendaharaan kosa kata mereka yang banyak mereka tetap sulit untuk menggunakannya dalam percakapan. Mereka hanya menggunakan kosa kata tersebut dalam penerjemahan kitab saja. Akan tetapi ada sebagian dari siswa di kelas Ma'had 'Aly Marhalah Ula putri ada yang sudah memiliki dasar (basic) bahasa arab dan mereka pun dapat dengan mudah serta cepat dalam memahami isi dari kitab kuning.

Pembelajaran di lembaga tersebut menuntut para siswa untuk bisa membaca serta memahami kitab gundul dengan bantuan kamus dan kitab-kitab yang berkaitan dengan nahwu dan shorf sebagai alat bantu membaca teks Arab tersebut. Suasana belajar di Ma'had 'Aly Marhalah Ula sudah kondusif karena lebih sering menggunakan metode diskusi yang dimaksudkan agar para siswa mandiri dalam memahami dan menguasai substansi teks yang dibaca.

Para siswa dapat dikatakan mampu membaca teks Arab jika sudah sesuai dengan kriteria kelancaran membaca dan kaidah kebahasaannya. Mereka memiliki banyak kosa kata yang di dapat saat mencari makna

\footnotetext{
${ }^{5}$ Tamam, Badrut, Al-Ijaz, Malang, 2013
} 
satu persatu kata dari kitab, akan tetapi hanya sebagian saja yang dapat menggunakan kosa kata tersebut dalam kehidupan sehari-hari. Namun terkadang mereka paham dengan bahasa Arab yang disampaikan oleh ustadz (guru) saat menjelaskan materi.

Peneliti dapat mengamati kemampuan membaca para siswa atas dasar nilai yang didapatkan oleh para siswa dari ujian lisan (membaca kitab), dengan nilai rata-rata 83. Sedangkan dari kemampuan berbicara dapat diketahui dari kemampuan berbicara dapat diketahui dari hasil percakapan peneliti dengan para siswa.

\section{METODE PENELITIAN}

Dalam penelitian ini memuat uraian tentang metode penelitian, langkah-langkah penelitian secara operasional yang meliputi: a) Rancangan Penelitian, b) Populasi, c) Instrument Penelitian, d) Metode Pengumpulan Data, dan e) Analisis data

Pendekatan penelitian ini menggunakan pendekatan kuantitatif. Penelitian kuantitatif adalah suatu penelitian di mana datanya dinyatakan dalam bentuk data kuantitatif. Data kuantitatif yaitu data yang berwujud angka-angka bisa diperoleh dari hasil penjumlahan (menghitung) atau bisa juga hasil pengukuran dan analisis kuantitatif yang disebut statistik. $^{6}$

Subyek penelitian Dalam penelitian ini yang menjadi subyek penelitian adalah Asrama Ma'had 'Aly Marhalah Ula, karena di Asrama ini lebih konsentrasi pada pembelajaran kitab kuning sehingga kemampuan dalam hal ini tidak diragukan lagi.

Teknik analisis data dalam penelitian kuantitatif menggunakan statistik yaitu menggunakan rumus product moment. Terdapat dua macam statistik yang digunakan untuk analisis data dalam penelitian, yaitu statistik deskriptif dan statistik inferensial. Berhubung penelitian yang dilakukan di sini termasuk penelitian populasi maka jelas

\footnotetext{
${ }^{6}$ Sugiyono, Metode penelitian Kuantitatif, kualitatif da $R \& D$, (Bandung;Aalfabeta,2008) cet.ke IV hlm.7
}

menggunakan statistik deskriptif dalam analisisnya

Populasi adalah seluruh individu yang menjadi subjek penelitian yang akan dikenai generalisasi, maka yang menjadi objek penelitian ini adalah seluruh siswi Ma'had 'Aly Marhalah Ula Putri Sukorejo Situbondo. Sedangkan fokus penelitian ini dibatasi hanya siswi yang memiliki kemampuan membaca kitab kuning serta dapat memahami dan menguasainya. Dan populasi dalam penelitian ini seluruh siswi di kelas Ma'had 'Aly Sukorejo Situbondo yang berjumlah 41 orang. Karena populasi hanya 41 orang jika dijumlahkan, maka secara otomatis 41 orang tersebut menjadi sampel. Dengan demikian ini disebut total sampling. karena kurang dari 100 maka populasi menjadi subjek penelitian. Hal ini sesuai dengan yang dikemukakan oleh suharsimi, apabila subjek kurang dari 100 lebih baik diambil semua sehingga penelitiannya merupakan penelitian populasi ${ }^{7}$.

\section{HASIL PENELITIAN DAN PEMBAHASAN}

Untuk membuktikan hipotesis penelitian yang diajukan, maka nilai hitung (r) tabel data kemampuan membaca kitab kuning terhadap keterampilan berbicara bahasa Arab dibandingkan dengan harga (r) tabel. Setelah dibandingkan, ternyata nilai hitung yang berjumlah 0,416 lebih besar dari tabel dengan taraf kepercayaan 5\% yang jumlahnya 0,308. Maka hipotesis penelitian kemampuan membaca kitab kuning terhadap keterampilan berbicara bahasa Arab siswi yang diajukan dapat diterima. Ini dapat dikatakan bahwa ada pengaruh kemampuan membaca kitab kuning (X) terhadap keterampilan berbicara bahasa arab (Y) siswi di Ma'had Aly Marhalah Ula putri. Dapat ditarik kesimpulan bahwa $\mathrm{H}_{\mathrm{I}}$ (yang menyatakan ada hubungan antara kemampuan membaca kitab kuning terhadap keterampilan berbicara bahasa arab) diterima. Sebaliknya $\mathrm{H}_{\mathrm{o}}$ (yang menyatakan tidak ada hubungan antara kemampuan memabaca kitab 
kuning terhadap keterampilan berbicara bahasa Arab) ditolak.

Dari hasil perhitungan dan dipadu dengan telaah pustaka, maka dapat dilihat bahwa kemampuan membaca kitab kuning berpengaruh terhadap keterampilan berbicara bahasa Arab, baik ditinjau dari sudut pandang teoritis maupun empirik. Hasil nilai hitung data diperolah dengan jumlah 0,416 setelah dikonsultasikan ke dalam koefisien nilai bergerak antara $0,400-0,599$ berarti mempunyai kategori sedang.

Dengan demikian dapat didiskusikan dan diinterpretasikan bahwa kemampuan membaca kitab kuning dapat berpengaruh terhadap keterampilan berbicara bahasa Arab dengan kategori sedang.

\section{KESIMPULAN}

Berdasarkan tinjauan teoritis dan hasil analisis data pengujian hipotesis dan pembahasan di atas data yang telah dikumpulkan dalam penelitian ini dapat disimpulkan bahwa ada pengaruh kemampuan membaca kitab kuning terhadap keterampilan berbicara bahasa Arab siswa di Ma'had Aly Marhalah Ula putri tahun pelajaran 2014/2015. Setelah dibandingkan, diperoleh nilai hitung yang berjumlah 0,416 lebih besar dari tabel dengan taraf kepercayaan $5 \%$ yang jumlahnya 0,308. Dapat dikatakan bahwa ada pengaruh kemampuan memabaca kitab kuning $(\mathrm{X})$ terhadap keterampilan berbicara bahasa Arab (Y) siswi di Ma'had Aly Marhalah Ula putri, yang dapat ditarik kesimpulan bahwa $\mathrm{H}_{\mathrm{I}}$ (yang menyatakan ada hubungan antara kemampuan membaca kitab kuning terhadap keterampilan berbicara bahasa Arab) diterima. Sebaliknya $\mathrm{H}_{\mathrm{o}}$ (yang menyatakan tidak ada hubungan antara kemampuan membaca kitab kuning terhadap keterampilan berbicara bahasa arab) ditolak.

\section{DAFTAR PUSTAKA}

Mustofa, Bisri dan Hamid, Abdul. Metode dan Strategi Pembelajaran Bahasa Arab. Malang: UIN-MALIKI Press, 2012.

Ainin, Moh. 2007, metodologi penelitian Bahasa Arab, Malang: Hilal Pustaka

Hermawan, Acep. Metodologi Pembelajaran Bahasa Arab, Bandung: Remaja Rosdakarya, 2011

Tamam, Badrut, Al-Ijaz, Malang

Sugiyono, Metode penelitian Kuantitatif, kualitatif $d a \quad R \& D$, (Bandung;Aalfabeta,2008) cet.ke IV

Arikunto Suharsimi, Prosedur Penelitian Suatu Pendekatan Praktek, Yogyakarta; Rineka Cipta, 2002 